\title{
Thermal treatment and leaching biochar alleviates plant growth inhibition from mobile organic compounds
}

\author{
Nigel V Gale ${ }^{\text {Corresp., }}{ }^{1}$, Tara E Sackett ${ }^{1}$, Sean C Thomas ${ }^{1}$ \\ ${ }^{1}$ Faculty of Forestry, University of Toronto, Toronto, Ontario, Canada \\ Corresponding Author: Nigel V Gale \\ Email address: nigel.gale@mail.utoronto.ca
}

Recent meta-analyses of plant responses to biochar boast positive average effects of between 10 and $40 \%$. Plant responses, however, vary greatly across systems, and null or negative biochar effects are increasingly reported. The mechanisms responsible for such responses remain unclear. In a glasshouse experiment we tested the effects of three forestry residue wood biochars, applied at five dosages $(0,5,10,20,50 \mathrm{t} / \mathrm{ha})$ to a temperate forest drystic cambisol as direct surface applications and as complete soil mixes on the herbaceous pioneers Lolium multiflorum and Trifolium repens. Null and negative effects of biochar on growth were found in most cases. One potential cause for null and negative plant responses to biochar is plant exposure to mobile compounds produced during pyrolysis that leach or evolve following additions of biochars to soil. In a second glasshouse experiment we examined the effects of simple leaching and heating techniques to ameliorate potentially phytotoxic effects of volatile and leachable compounds released from biochar. We used Solid Phase Microextraction (SPME) - gas chromatography - mass spectrometry (GC-MS) to qualitatively describe organic compounds in both biochar (through headspace extraction), and in the water leachates (through direct injection). Convection heating and water leaching of biochar prior to application alleviated growth inhibition. Additionally, growth was inhibited when filtrate from water-leached biochar was applied following germination. SPME-GC-MS detected primarily short-chained carboxylic acids and phenolics in both the leachates and solid chars, with relatively high concentrations of several known phytotoxic compounds including acetic acid, butyric acid, bisphenol and benzonoic acid. We speculate that variable plant responses to phytotoxic organic compounds leached from biochars may largely explain negative plant growth responses and also account for strongly speciesspecific patterns plant responses to biochar amendments in short-term experiments. 


\section{Thermal treatment and leaching biochar alleviates plant}

\section{2 growth inhibition from mobile organic compounds}

3

4 Nigel V. Gale* $^{* 1}$, TARA E. SACKetT ${ }^{1}$, and SeAn C. ThOMAS ${ }^{1}$

5

*Corresponding author: nigel.gale@mail.utoronto.ca

Abstract

Recent meta-analyses of plant responses to biochar boast positive average effects of between 10 and $40 \%$. Plant responses, however, vary greatly across systems, and null or negative biochar effects are increasingly reported. The mechanisms responsible for such responses remain unclear. In a glasshouse experiment we tested the effects of three forestry residue wood biochars, applied at five dosages $(0,5,10,20,50 \mathrm{t} / \mathrm{ha})$ to a temperate forest drystic cambisol as direct surface applications and as complete soil mixes on the herbaceous pioneers Lolium multiflorum and Trifolium repens. Null and negative effects of biochar on growth were found in most cases. One potential cause for null and negative plant responses to biochar is plant exposure to mobile compounds produced during pyrolysis that leach or evolve following additions of biochars to soil. In a second glasshouse experiment we examined the effects of simple leaching and heating techniques to ameliorate potentially phytotoxic effects of volatile and leachable compounds released from biochar. We used Solid Phase Microextraction (SPME) - gas chromatography - 
24 mass spectrometry (GC-MS) to qualitatively describe organic compounds in both biochar

25 (through headspace extraction), and in the water leachates (through direct injection). Convection

26 heating and water leaching of biochar prior to application alleviated growth inhibition.

27 Additionally, growth was inhibited when filtrate from water-leached biochar was applied

28 following germination. SPME-GC-MS detected primarily short-chained carboxylic acids and

29 phenolics in both the leachates and solid chars, with relatively high concentrations of several

30 known phytotoxic compounds including acetic acid, butyric acid, 2,4-di-tert-butylphenol, and

31 benzoic acid. We speculate that variable plant responses to phytotoxic organic compounds

32 leached from biochars may largely explain negative plant growth responses and also account for

33 strongly species-specific patterns of plant responses to biochar amendments in short-term

34 experiments. 
47 Introduction

48

49

"Biochar" is the term given to charcoal intended for use as a soil amendment, commonly

50 derived from pyrolysis of biomass residues from forestry and agriculture. Biochar has been

51

52

53

54

55

56

57

58

59

60

61

62

63

64

65

66

67

68

69

recently heralded for its ability to increase productivity and ameliorate poor soil conditions, while mitigating anthropogenic climate change by enhancing soil carbon sequestration (Lehmann, 2007; Biederman \& Harpole, 2013). Many biochars exhibit high surface areas, $\mathrm{pH}$, and cation exchange capacity (CEC), properties that can increase soil fertility, nutrient availability, and water retention (Major et al., 2010; Atkinson, Fitzgerald \& Hipps, 2010). Metaanalyses of field and greenhouse studies suggest average increases of $10-30 \%$ in aboveground biomass in response to applications of biochar for agricultural crops (Jeffery et al., 2011; Liu et al., 2013; Biederman \& Harpole, 2013), and larger increases averaging 40\% for trees (Thomas \& Gale, 2015). Plant responses, however, vary greatly across species and ecosystems, and null or negative biochar effects are common (Jeffery et al., 2011; Spokas et al., 2012). Thus, null and negative responses of plants to biochar have received recent research attention (Buss \& Mašek, 2014; Kołtowski \& Oleszczuk, 2015; Domene et al., 2015; Buss et al., 2015). soils, with much lower responses commonly reported in temperate soils (Jeffery et al., 2011; Thomas \& Gale, 2015). Strong positive plant responses to biochar in infertile, acidic tropical soils are likely mainly due to a combination of soluble $\mathrm{P}$ from biochar and $\mathrm{P}$ retention by biochar (Mukherjee \& Zimmerman, 2013), sorption of salts or metals by biochar (Park et al., 2011; Lashari et al., 2013), and soil liming effects (Major et al., 2010). Recent results by Pluchon et al., 
70 (2014) suggest a positive relationship between $\mathrm{P}$ in wood-derived biochar and growth responses

71 of tree seedlings, indicating possible P limitation in boreal soils. The sorption of phenolic

72

73

74

compounds by biochar has also been suggested to contribute to high plant responses to biochar in some boreal soils (Wardle, Zackrisson \& Nilsson, 1998). Increased soil basicity from strongly basic biochars can limit the availability of $\mathrm{Ca}, \mathrm{Mg}, \mathrm{P}$ and other nutrients (Major et al., 2010; Makoto et al., 2011; Marks, Alcañiz \& Domene, 2014), and such responses are expected to be most pronounced on soils that are already neutral to basic (Kloss et al., 2014). Biochar's affinity for cations and sorption of anions can also 'lock up' certain soil nutrients, in particular, mineralized N (Glaser, Lehmann \& Zech, 2002; Asai et al., 2009).

(1)

80

A rather unexplored explanation for null and negative plant responses to biochar is related to plant exposure to volatile compounds generated during pyrolysis and re-condensed as liquids on biochar's surface or trapped as gases within pore spaces (Spokas, Baker \& Reicosky, 2010; Spokas et al., 2011; Hale et al., 2012). Pyrolysis converts the polymeric constituents lignin, cellulose, and hemicellulose (as well as starches, lipids, and "extractives" such as terpenoid and phenolic compounds) into liquid bio-oil, charcoal, and non-condensable gases (Shafizadeh, 1982). Many of the compounds generated are "mobile" (Buss \& Mašek, 2014; Buss et al., 2015): they are either water soluble or volatile, i.e., have high vapor pressures under ambient conditions temperatures and pressure conditions (Yu et al., 2007). Such compounds include low molecular weight alcohols, ketones, aliphatic acids, and phenols (Buss et al., 2015; Lievens et al., 2015), as well as larger polyaromatic hydrocarbons (PAHs) (Hale et al., 2012; Kołtowski \& Oleszczuk, 2015; Domene et al., 2015). Other mobile and potentially toxic compounds produced during pyrolysis such as salts and heavy metals are generally detected at 
93 only low levels in biochars derived from non-contaminated feedstocks (Domene et al., 2015), are

94 strongly sorbed by biochar (Thomas et al., 2013; Lucchini et al., 2014), and are therefore less

95 likely to be an important component of toxicity responses to biochars (Buss \& Mašek, 2014;

96 Kołtowski \& Oleszczuk, 2015; Domene et al., 2015; Lievens et al., 2015).

97

98

100

101

102

103

104

105

106

107

108

109

110

111

112

113

114

115

The quantities and types of mobile organic compounds present in biochar will depend on the composition of the feedstock and the conditions of pyrolysis. Biomass feedstocks differ greatly in the composition of cellulose, hemicellulose, and lignin and generate a diversity of volatile compounds. Woody biomass generally has higher concentrations of lignin and cellulose (20-25\% and $\sim 45 \%$, respectively) than non-woody grasses (which typically have lignin concentrations of 3-12\%: Morrison 1972). There is, however, remarkably high variation in these constituents among woody species (Petterson, 1984). Thermal decomposition of cellulose occurs around $400^{\circ} \mathrm{C}$ and releases the highest proportion of labile, aliphatic compounds. Higher pyrolysis temperatures $\left(>400^{\circ} \mathrm{C}\right)$, where decomposition of lignin dominates, produce syn-gases containing higher concentrations of carbon dioxide $\left(\mathrm{CO}_{2}\right)$, ethylene $\left(\mathrm{C}_{2} \mathrm{H}_{4}\right)$, and ethane $\left(\mathrm{C}_{2} \mathrm{H}_{6}\right)$ (Bilbao, Millera \& Arauzo, 1989; Kloss et al., 2012). Re-condensation of these volatiles from cold spots due to poor insulation and blockage of syn- or pyrolysis gases, and their capture within biochar pores, has been suggested in a number of studies (Spokas et al., 2011; Buss \& Mašek, 2014). Mobile organic compounds have been characterized in a number of wood-derived biochar's produced at moderate pyrolysis temperatures $350-600{ }^{\circ} \mathrm{C}$ (Spokas et al., 2011; Buss et al., 2015; Lievens et al., 2015) and have demonstrated toxicity in a variety of organisms (Buss \& Mašek, 2014; Kołtowski \& Oleszczuk, 2015). Fast pyrolysis and gasification biochars have been suggested to exhibit the greatest phytotoxic effects (Rogovska et al., 2012). 
118 stimulating plant growth at low dosages but inhibiting growth at high dosages (Baldwin et al.,

119 2006; Calabrese, Iavicoli \& Calabrese, 2012). The aqueous fraction of the bio-oil, commonly

120 referred to as "wood vinegar", contains primarily acetic acid and phenolic compounds. When

121 diluted $\left(10^{3}-10^{7}\right.$ times $)$, wood vinegars commonly stimulate plant growth $(\mathrm{Mu}$, Uehara \&

122 Furuno, 2003; 2004), but remain potent insecticides and fungicides (Yatagai et al., 2002;

123 Velmurugan, Han \& Lee, 2009). At higher concentrations these compounds can be herbicidal.

124 Buss and Masek (2014) found germination inhibition in cress from leached compounds from

125 acidic chars $(\mathrm{pH}=3.64)$, attributed to low molecular weight organic acids and phenols (Buss et

126 al., 2015). Because ethylene is a gaseous plant hormone involved in growth regulation, plant

127 stress signalling, and tissue senescence (Abeles, Morgan \& Saltveit, 1992; Ortega-Martínez et

128 al., 2007), its evolution from freshly produced biochars (Fulton et al., 2013) is another plausible

129 mechanism for reduced growth responses. Ethylene evolution from biochars would also be

130 expected to result in pronounced changes in plant growth form and reproduction (Abeles,

131 Morgan \& Saltveit, 1992). To our knowledge phytotoxicity from mobile organic compounds

132 released by biochar has not been specifically tested in plant growth beyond the germination

133 stage, or in plants grown in soil media other than pure sand.

134

135 To test the effects of biochar derived from forestry residues on temperate plant

136 performance in a managed system, we grew Lolium multiflorum and Trifolium repens in a

137 factorial greenhouse experiment. We examined effects of addition rate (0-50 t/ha), biochar type

138 (three different biocharss produced from sawdust), and application method (top-dressing vs. 
139 complete soil mixes). We hypothesized that plant growth would increase overall, and would vary

140 with biochar type, dosage, and application method. Because of exclusively negative and null

141 effects observed in the first experiment, in a second greenhouse experiment, we examined the

142 effects of simple post-treatment biochar processing techniques to ameliorate potentially toxic

143 effects of mobile organic compounds released by biochars. Because volatiles sorbed by biochars

144 during pyrolysis exist in liquid (re-condensed) and gaseous phases (Spokas, Baker \& Reicosky,

145 2010; Spokas et al., 2011; Hale et al., 2012), and can be water-leached (Jonker \& Koelmans,

146 2002; Hale et al., 2012; Buss et al., 2015; Lievens et al., 2015), we tested both biochar leaching

147 and heating treatments on the growth responses of Lolium multiflorum. We hypothesized that

148 water leaching and convection heating would significantly improve plant responses by reducing

149 volatile and leachable compounds. We predicted more pronounced growth enhancement with

150 biochars that were leached longer and heated at higher temperatures. We also hypothesized that

151 application of biochar leachate would significantly inhibit plant growth. To identify candidate

152 molecules involved in toxicity responses, we examined volatile and leachable organic

153 compounds using semi-quantitative Solid-Phase-Micro-Extraction (SPME)- gas chromatography

154 - mass spectrometry (GC-MS) of solid chars and water leachates.

155

156 Materials and Methods:

157

\section{Study Species}

159

160

The herbaceous species Lolium multiflorum Lam. (annual ryegrass: hereafter ryegrass)

161 and Trifolium repens L. (white clover: hereafter clover) are commonly used as temperate forage 
162 crops, for erosion control (Ledgard \& Steele, 1992), and are early colonizers of temperate sites

163 following fire events (Keeley et al., 1981; Milberg, 1995). Ryegrass is a fast growing, nutrient-

164 demanding annual dicot that can tolerate a range of soil conditions. Clover is a slow-growing

165 perennial monocot that has low nutrient requirements as its associated root symbionts can

166 biologically fix atmospheric nitrogen (Ledgard \& Steele, 1992). Clover in previous studies has

167 shown increased nitrogen fixation in soils amended with biochar (Quilliam, DeLuca \& Jones,

168 2012). Because of this contrast in life histories, resource use, and growth forms, we expected

169 that changes to soil properties would have differential effects on growth and performance in

170 these two species. Because larger effects of biochar on growth have been reported for annuals

171 over perennials (Biederman \& Harpole, 2013), and since the strongest negative effects in

172 experiment 1 were detected in L. multiflorum, it was selected to test if biochar post-treatments

173 could enhance plant responses in experiment 2.

174

175 Experiment 1: Effects of amount, type, and application method:

176

177

Plants were grown in $11.33 \mathrm{~cm}^{2}$ surface area growth containers (Ray Leach SC-10 cone-

tainers (Stuewe and Sons, Tangent, OR, USA) $21 \mathrm{~cm}$ depth, $164 \mathrm{ml}$ volume, with fiberglass

179 screen placed at the base of the container to reduce soil loss in soil amended with three sawdust-

180 derived biochars (Table 1): 1) sugar maple sawdust pyrolyzed in a batch unit at $475^{\circ} \mathrm{C}(\mathrm{MB})$

$181(\sim 1.5 \mathrm{~h}$ total pyrolysis time $), 2)$ spruce sawdust pyrolyzed in a batch unit at $422^{\circ} \mathrm{C}(\mathrm{SB})(\sim 1.5 \mathrm{~h}$

182 total pyrolysis time), and 3) 80\% sugar maple, 20\% yellow birch sawdust pyrolyzed in a flow-

183 through pyrolysis unit at $575^{\circ} \mathrm{C}(\mathrm{MFT})(\sim 0.5 \mathrm{~h}$ total pyrolysis time). The batch unit was purged

184 with nitrogen gas, and the flow-through unit consisted of a long feed-screw that resulted in tight 
185 packing of feedstock to limit oxygen access during pyrolysis. Biochars were applied at 5, 10, 20, 186 and $50 \mathrm{t} /$ ha either mixed into the soil or applied to the surface; the control treatment consisted of 187 soil without biochar. These biochars were selected for the present study as they are expected to 188 be used in industrial scale applications and their effects on temperate plant and soil functioning 189 have been the subject of recent study (Sackett et al. 2015, Noyce et al., 2015, 2016, Mitchell et 190 al. 2015). Five replicates were used for the biochar treatments and 10 replicates for were used for 191 the control treatments (to increase statistical power for control vs. treatment contrasts). In total, 4 192 addition rates $(5,10,20,50 \mathrm{t} / \mathrm{ha}) \times 3$ biochars $(\mathrm{MB}, \mathrm{SB}, \mathrm{MFT})$ x 2 application methods (mixed, 193 top-dressed) x 5 replicates), + (10 control plants (no biochar, field soil) $\times 2$ species (clover, 194 ryegrass), resulted in $n=260$ plants. Biochar use is expected to target acidic, coarse-textured 195 soils of low nutrient status. Accordingly, the soil used in the experiment was a drystric 196 cambisolic field soil (or drystric brunisol based on the Canadian System of Soil Classification 197 (1998)), that was sandy-loam in texture (Table 2), collected in the summer of 2011 from the 198 uppermost mineral layer $(<10 \mathrm{~cm})$ of a managed forest at Haliburton Forest and Wildlife Reserve, Haliburton, ON, Canada $\left(45^{\circ} 15^{\prime} \mathrm{N}, 78^{\circ} 34^{\prime} \mathrm{W}\right)$, and re-used from control treatments in 200 a previous experiment. All plants were supplemented with $0.082 \mathrm{~g}$ of slow-release NPK fertilizer 201 representing relatively high inputs found in disturbed temperate herbaceous systems (Garbutt \&

202 Bazzaz 1987): addition rates are $130 \mathrm{~kg} / \mathrm{ha}(\mathrm{N}), 5 \mathrm{~kg} / \mathrm{ha}(\mathrm{P}), 48(\mathrm{~K}) \mathrm{kg} / \mathrm{ha}$, respectively.

203 Germination was initiated by placing seeds on greenhouse benches in water-saturated 204 vermiculite. One seedling was transplanted into each prepared treatment pot 5 days after 205 germination. Fertilizer was applied following planting. A randomized block design was employed using 5 blocks in which plants were randomly placed, with each treatment

207 combination was represented once in each block. Supplemental lighting was applied to maintain 
208 a 16-h photoperiod. The experimental growth period was 28 days (Dec. 20, 2012 - January 17, 209 2013) and 41 days (Dec. 20, 2012 - January 30, 2013) for ryegrass and clover, respectively.

210 Average daily greenhouse temperature throughout the experiment was $16.5^{\circ} \mathrm{C}$ with average daily

211 maximums and minimums were $20^{\circ} \mathrm{C}$ and $16^{\circ} \mathrm{C}$, respectively. All plants were top watered semi-

212 daily (daily to every other day) to saturation and allowed to drain.

213

214 Experiment 2: Modulation of effects through leaching and heating treatments:

215

216

To test the effect of pre-application biochar heating and leaching on plant performance,

217

218

219

220

221

222

223

224

225

226

227

228

229

230

ryegrass was grown in pots (as above) with additions of MFT biochar processed to remove mobile compounds before additions. Because there was no difference in plant performance between biochars in experiment 1 , suggesting similar compounds responsible for the observed phytotoxicity, only MFT was selected for experiment 2 since it was most available at the time of experimental set-up. Two leaching treatments and 3 heating treatments were applied to biochars before being applied as both mixed and top-dressings at a dose of $10 \mathrm{t} / \mathrm{ha}(\mathrm{n}=8)$. We leached biochar with 1:1 (v:v) mixture of biochar to de-ionized water for either $0.5 \mathrm{~h}(\mathrm{WW}-0.5)$ or $24 \mathrm{~h}$ (WW-24) on an oscillating table. Biochar-water slurries were then suction filtered using Whatman \#4 filter paper, and the filtrate captured. Filtrate from the leachings was collected and $5.0 \mathrm{~mL}$ of filtrate was applied as a separate treatment to plants $(\mathrm{n}=8)$ one day following planting (Leach-0.5, Leach-24). Leached biochars were then rinsed with $400 \mathrm{~mL}$ of de-ionized water, suction filtered, and applied to their respective treatments. Biochars were placed in a convection oven to be heat treated for $24 \mathrm{~h}$ at 50 (Heat-50), 100 (Heat-100), and $150{ }^{\circ} \mathrm{C}$ (Heat-150), cooled, and added to soil. To assess the effect of leaching and heating, un-processed biochar treatments 
231 (mixed and top-dressing) were also established $(\mathrm{n}=8)$, as well as a control treatment containing

232 no biochar $(n=10)$. In total, 2 leaching treatments +3 heating treatments +1 unprocessed biochar

$233 \times 2$ application methods $\times 8$ replicates +2 leachate additions $\times 8$ replicates +10 controls, resulted

234 in $\mathrm{n}=122$ plants. Soil used in the experiment was the same field soil as used in experiment 1

235 (Table 2). Experimental growth period was 28 days (Jan. 28 - Feb 26, 2013). Average daily

236 greenhouse temperature was $18^{\circ} \mathrm{C}$, with daily average maximum and minimum temperatures of

$23721^{\circ} \mathrm{C}$ and $15^{\circ} \mathrm{C}$, respectively. All plants were top watered daily to saturation.

238

239

\section{Biochar and soil characterization}

240

241

Biochar was characterized (Table 1) as follows: electrical conductivity (EC) and pH were

242

measured in a 1:20 (w:v) biochar to $\mathrm{H}_{2} \mathrm{O}$ solution using pH and EC probes (Rajkovich et al., 2012). Particle size distribution was determined from dry sieving following the ASTM D2862 method (ASTM, 1999). Total moisture content, ash content, volatile matter, and organic matter content were determined by oven drying at $105^{\circ} \mathrm{C}$, by muffle furnace combustion at $750^{\circ} \mathrm{C}$, by heating at $950^{\circ} \mathrm{C}$ in sealed containers for 7 minutes, and through loss on ignition for 0.5 hours in a muffle furnace at $500{ }^{\circ} \mathrm{C}$ by following ASTMD1762-84 (ASTM, 2007). Total carbon and 248 nitrogen were quantified using combustion analysis using an Elementar VarioMax (Elementar Analysensteme $\mathrm{GmbH}$, Hanau, Germany). Total $\mathrm{P}$ and cations $\left(\mathrm{K}^{+}, \mathrm{Ca}^{+}\right.$, and $\left.\mathrm{Mg}^{2+}\right)$ for $\mathrm{MB}$ and SB were obtained using a sulphuric acid digest and Mehlich III extraction, respectively, then

252 et al., 2015). 
253 Soil characterization (Table 2) was conducted at the Agriculture and Food Laboratory,

254 University of Guelph, Guelph, ON.

\section{2.4. Plant growth measurements}

256

For both experiments, above- and below-ground plant biomass and leaf area were

258

259

260

261

262

263

measured at the end of the experiments. Because leaf area indicates plant carbon gain, nutrient uptake, and physiological performance, and has demonstrated responsiveness to biochar additions (Graber et al., 2010), we measured leaf area using a Li-3100C leaf area scanner with a resolution of $1 \mathrm{~mm}^{2}$ (LiCor biosciences, Lincoln, Nebraska, USA). Below-ground biomass was separated from soil and biochar media by dry sieving followed by gentle washing of roots with water. Above-ground and below-ground biomass, including scanned leaves, was dried for $48 \mathrm{~h}$ at $65^{\circ} \mathrm{C}$ and weighed. Since increased nutrient uptake, nitrogenase activity, and nodulation has been reported in legumes amended with biochar (Rondon et al., 2007; Quilliam, DeLuca \& Jones, 2012), before drying we counted nodules on clover roots under a dissection microscope. Only nodules with leghemoglobin were scored (visible red colour).

\section{SPME - GC-MS of volatile and leachable compounds}

We followed Rombola et al. (2015) for qualitative analysis of SB and MB solid char and their water leachates, with minor modifications. Briefly, for headspace (HS)-SPME of solid biochars, 0.5 grams of sample was placed in a $10 \mathrm{~mL}$ headspace vial and spiked with $2.0 \mathrm{~mL}$ of $1 \mathrm{ppm} O$-eugenol as an internal standard. $\mathrm{HS}$ vials were placed on a heating plate at $150^{\circ} \mathrm{C}$ for 30 min while a Carboxen-PDMS fiber was inserted into the top $1 \mathrm{~mL}$ of the headspace vial on a 
276 Agilent 7890A GC system. Following heating the fiber was inserted into the injector and 277 analytes thermally desorbed at $250^{\circ} \mathrm{C}$ for 10 min prior to direct injection. $\mathrm{GC}$ analysis was 278 carried out using a DB-WAX column ( $20 \mathrm{~m}$ length, $0.20 \mu \mathrm{m}$ width, $0.10 \mathrm{~mm}$ i.d) following the 279 thermal program in Rombolà et al. (2015): $80^{\circ} \mathrm{C}$ for $5 \mathrm{~min}$, then $10^{\circ} \mathrm{C} / \mathrm{min}$ to $250^{\circ} \mathrm{C}$ for a total 280 run time of 28 min. MS analysis was carried out on a 5975C Agilent MS with peak identification 281 conducted using the NIST reference spectral library. Detection was made under electron 282 ionization at $60 \mathrm{~m} / \mathrm{z}$ and an acquisition of $1 \mathrm{scan} / \mathrm{s}$. Hits with over $70 \%$ probability and relative 283 match factors higher than 800 were considered; peaks of internal standards were confirmed.

Direct injection (DI)-SPME of leachates was performed on $3 \mathrm{~mL}$ of dionized water leachates (following washing method used for MFT) with $1.0 \mathrm{~mL}$ of $2 \mathrm{M} \mathrm{KH}_{2} \mathrm{PO}_{4}$ buffer. This sample was spiked with $2.5 \mathrm{~mL}$ of $1 \mathrm{ppm} O$-eugenol, and $2.5 \mathrm{~mL}$ of $5 \mathrm{ppm}$ 2-ethyl butyric acid 288 as internal standards, and then placed into $10 \mathrm{~mL}$ headspace vials. The Carboxen-PDMS fiber was directly inserted into the solution under magnetic stirring for $30 \mathrm{~min}$ at $250^{\circ} \mathrm{C}$. GC-MS analysis was performed as above. Quantification of analytes was not attempted due to the unreliability of SPME in producing accurate calibration curves with internal standards, a problem also noted in Spokas et al. (2011). All GC-MS analysis were conducted at the Teaching and Research in Analytical Chemistry and Environmental Sciences (TRACES) Centre, University of Toronto, Scarborough (1065 Military Trail, Toronto, ON, M1C 14A). SPME-GC-MS was conducted on SB and MB only since MFT was no longer available at the time of quantification. 

combinations, have multiple controls, and test other treatments of interest (i.e. have an 301 augmented factorial design); we therefore used multiple contrasts to test our hypotheses

302 (following Schaarshmidt \& Vaas, 2009). This allows the pair-wise comparison of both individual 303 treatments (e.g., MFT biochars vs control) and groups of treatments (e.g, all biochars at 5 t/ha vs 304 control). The test statistic for each contrast was calculated from:

$\mathrm{T}=\left(\Sigma c_{i} \hat{\mathrm{u}}_{\mathrm{i}}\right) /\left(\sigma \Sigma c_{i} / n_{i}\right)$

Where $\hat{\mathrm{u}}_{\mathrm{i}}$ is the mean estimate derived from the linear model described in Bretz, Hothorn \& 309 Westfall (2002), and $c_{i}$ is the contrast coefficient, and $\sigma$ represents the residual error. Contrast 310 coefficients are shown in supplementary tables S1, S2, and S3. Simultaneous confidence 311 intervals $(95 \%)$ were derived from:

$\left[\Sigma c_{i} \hat{\mathrm{u}}_{\mathrm{i} \pm}\left(\mathrm{q}_{1}-\alpha, M, R\right) \sigma\left(\sqrt{\Sigma} c_{i}^{2} / n_{i}\right)\right]$

315 Where the critical value, $\left(\mathrm{q}_{1}-\alpha, M, R\right)$, is calculated from the multivariate $\mathrm{t}$-distribution with 316 dimension $M$ and correlation matrix $R$ (see Bretz, Genz \& Hothorn, 2001) for critical value 317 determination. Simultaneous confidence intervals were used to display the magnitude and 318 direction of mean comparisons. Analyses were done using the 'multcomp' package (Bretz, 319 Hothorn \& Westfall, 2002; Hothorn et al., 2008) in the statistical software R version 3.1.0 (R 320 Core Team, 2012). Many biochar studies have complex treatment structures and treatments of 321 interest: we expect wide use of multiple contrast tests in future biochar research as an effective 
322 and informative analysis tool, we have therefore included the R script as a supplementary file for 323 use as a reference.

324

325

To test the effect of biochar addition rate on plant performance traits we performed linear

326 regressions with above- and below-ground biomass and leaf area as response variables and with biochar dosage as the independent variable. We log-transformed response variables to represent effect sizes metrics reported in recent meta-analyses of plant growth responses to biochar (Liu et al., 2013; Biederman \& Harpole, 2013; Thomas and Gale 2015) following: $R R=\ln (B / C)$, where $\mathrm{RR}$ is the response ratio metric, $\mathrm{B}$ is the mean biomass of biochar treated plants, and $\mathrm{C}$ is the mean biomass of control plants without biochar. Regressions were performed for each of the three biochars used in the experiment and were not separated by application method (topdressing vs complete mixtures). Analyses were conducted in the statistical software $\mathrm{R}$ version 3.1.0 (R Core Team, 2012).

Results

Experiment 1: Negative and null effects on plant growth regardless of biochar type, dosage, or application method

342 regardless of biochar type, dosage, or application method. The average of the three mean

343 responses of all treatments using MFT, SB, and MB revealed decreased ryegrass aboveground

344 biomass relative to controls by $25 \%$, leaf area by $17 \%$, and belowground biomass by $35 \%$ (Fig 1 , 
345 Table 3). All three individual biochar types negatively impacted all growth traits examined in

346 ryegrass (Fig 1), but had no significant effect on clover growth traits (Table 3). Nodulation in

347 clover did not differ across treatments (Table S2). All performance traits in ryegrass, but not

348 clover, were inhibited by biochar at all dosages and this inhibition decreased with biochar

349 addition rate. Linear regressions detected significant negative relationships of above- and below-

350 ground biomass and leaf area with increasing biochar addition rate for all three biochars used in

351 almost all comparisons (Fig. 2). The mean of all the biochar treatments at $50 \mathrm{t} /$ ha showed

352 reduced ryegrass aboveground biomass by $34 \%$, leaf area by $28 \%$, and belowground biomass by

$35343 \%$ (Fig 1, Table 3). Mixing biochar directly into the soil was significantly less inhibiting than

354 direct surface applications for all growth parameters in ryegrass (Fig 1, Table 3).

355

356

Experiment 2: Heating and leaching biochar prior to application alleviates growth

357 inhibition in ryegrass

358

359

Ryegrass grown in biochar either water leached or convection heated prior to application 360

performed significantly better than ryegrass grown in un-processed biochar (Fig 3). Unprocessed

361

biochar reduced ryegrass aboveground biomass by $24 \%$ (Fig 3,a), leaf area by $22 \%$, and

362

belowground biomass by $28 \%$ (Fig 3,b) (Table 4). There was no difference between mixed and

363

top-dressed applications of the un-processed biochar. Post-treating the biochar by water leaching

364 for 24 hours or heat treatment $\geq 100^{\circ} \mathrm{C}$ significantly increased aboveground biomass as compared to un-processed biochar (Fig. 3a). Biochar that was water-leached for 24 hours increased aboveground biomass by $34 \%$, and belowground biomass by $22 \%$ compared to unprocessed biochar (Table 4). Convection heating of biochar for 24 hours at $100{ }^{\circ} \mathrm{C}$ and at $150{ }^{\circ} \mathrm{C}$ 
368 increased leaf area by $20 \%$, and $23 \%$, respectively (Fig 3, Table 4). However, aboveground

369 biomass and leaf-area of ryegrass grown with any processed biochars did not differ significantly

370 from ryegrass grown in control (without biochar) soil (Table 4).

371

372

The water-based filtrate from biochar leaching applied immediately following

373

transplantation significantly decreased growth of ryegrass as compared to plants grown in control 374 soil (Table 4). Filtrate applied from the 24 hour leaching most strongly inhibited growth, decreasing aboveground biomass by $40 \%$, leaf area by $27 \%$, and belowground biomass by $36 \%$

(Fig 4, Table 4). Filtrate from the 30-minute water leaching was less inhibiting, decreasing leaf area by $18 \%$. The significant decrease in ryegrass growth traits due to the application of filtrate was similar in magnitude to the application of un-processed biochar (Fig 4, Table 3).

\section{Mobile organic compounds detected with SPME-GC-MS}

381

SPME-GC-MS of solid chars and leachates revealed primarily short-chained carboxylic acids, phenols, hydrocarbons; with notable differences between chars (Fig. 5). HS-SPME of MB qualified acetone, acetonitrile, acetic acid, pentanone, and butyric acid (Fig. 5A). HS-SPME of SB revealed acetic acid, benzene, decane, methyl isocyanide, ethylbenzene, dodecane, and 6methyoxybenzofuran (Fig 5B). DI-SPME of MB leachates revealed acetic acid, butyric acid, valeric acid, phenol, 2,4-di-tert-butylphenol and benzoic acid (Fig. 5C). DI-SPME of SB leachates similarly detected acetic acid, butyric acid, 2,4-di-tert-butylphenol and benzoic acid; however, oxime, and 5-methyoxybenzofuran were also detected (Fig. 5D). 
391

Discussion

392

393 The negative effects of three sawdust biochars on ryegrass growth and the null response of 394 clover growth observed in these experiments are contradictory to average plant growth trends 395 396 397 described in recent meta-analyses (Jeffery et al., 2011; Liu et al., 2013; Biederman \& Harpole, 2013; Thomas \& Gale, 2015); however, these results are similar to the null to negative responses noted qualitatively in $\sim 20 \%$ of prior studies (Spokas et al., 2012). High dosage (50 t/ha) and direct soil-surface applications of biochar (as opposed to mixing into the soil) were most inhibitory. Similar to Biederman \& Harpole (2013), who report negative (but not significant) biomass response slopes to increasing biochar additions in almost half of 20 studies of plant responses to biochar in their meta-analysis, we detect a strongly negative linear relationship of performance traits to increasing biochar additions in ryegrass. Convection heating and waterbased leaching of biochar prior to application alleviated growth inhibition of ryegrass. SPMEGC-MS suggests a number of common compounds which are volatile and leachable, and which we infer are generated by the pyrolysis process and re-condensed on or trapped within biochar (similar to Hale et al., 2012; Spokas, 2013; Buss \& Mašek, 2014; Kołtowski \& Oleszczuk, 2015; Domene et al., 2015; Buss et al., 2015; Lievens et al., 2015). The inhibition of ryegrass growth resulting from application of biochar leachate generated by water leaching was similar to that of un-processed biochar applied to soils (Table 4), suggesting the water soluble organic compounds qualified are very likely responsible for the growth inhibition observed. 
414 a nitrogen immobilization mechanism (Glaser, Lehmann \& Zech, 2002; Asai et al., 2009; Deenik

415 et al., 2010), to which clover, as a legume, is more resistant. Nitrogen immobilization from

416 biochar has been observed in temperate soils (see Kloss et al., 2014; Rajkovich et al., 2012), and

417 can further be depleted by microorganisms that readily use other biochar derived leachates, such

418 as high volatile matter and labile carbon (Deenik et al., 2010; Marks, Alcañiz \& Domene, 2014).

419 However, recent published work using two of these biochars (MB and SB) at the field site where 420 our experimental soils were obtained (Haliburton, ON), showed that biochar caused no change to 421 mineralized nitrogen, when applied at $5 \mathrm{t} / \mathrm{ha}$ as a top-dressing in a temperate forest stand (Sackett 422 et al., 2015).

423

We suggest that species-specific phytotoxicity responses to volatile and leachable compounds from fresh biochar at least partially explains null and negative growth responses to biochar addition, and also contributes to the variation in plant responses to biochar. Several studies have now demonstrated phytotoxicity to fresh biochar, but there is little information regarding the source and chemistry of toxics involved (Buss \& Mašek, 2014; Kołtowski \& 429 Oleszczuk, 2015). Hajaligol et al. (2001) show rapid thermal decomposition of cellulosic materials at low to moderate $\left(<300{ }^{\circ} \mathrm{C}\right)$ pyrolysis temperatures forming a primary char that is capable of a second chemical transformation at moderate to high temperatures $\left(>400^{\circ} \mathrm{C}\right)$. This

432 first decompositions typically produces aldehydes, alcohols, and ketones, while the secondary 433 transformation is likely to produce hydrocarbons and aromatics (Hajaligol et al. 2001). We

434 found evidence of both decompositions from moderate temperature pyrolysis of woody

435 feedstocks used to produce the biochars in our study. Low to moderate temperature pyrolysis of 436 woody-feedstocks are thus likely to produce a high concentration of primary decomposition 
437 derived low molecular weight compounds due to the high cellulose and lignin concentrations.

438 Therefore, careful selection of feedstocks is necessary when creating biochars since trade-offs

439 for restoration goals like high sorptive properties vs potential phytotoxicity are likely.

440

441

442

443

444

445

446

447

448

449

450

451

452

453

454

455

456

457

458

459

We suggest two causes for contamination of biochar from these volatile and mobile compounds: First, that pyrolysis retention times for biochar production is too short for sufficient evolution and diffusion through the pyrolysis system without being sorbed by biochar or trapped within its porous structure. This is especially likely in fast pyrolysis, although "slow" pyrolysis retention times of 0.5-2 hours (or less) may also be too short (such as the biochar used here or in Novak et al. 2014). The second cause for contamination of biochar may be due to recondensation of volatiles during pyrolysis either from poor insulation or blockage in pyrolysis systems, and/or can occur as biochar cools (Spokas et al., 2011; Buss \& Mašek, 2014). We suspect that one or both of these issues is common since mobile and volatile compounds are discovered in most biochars (Spokas et al. 2011), and since null and neutral plant responses are widely observed to biochar (Spokas et al. 2012). Much further investigation is necessary to resolve contamination of biochars, and particular focus should be given on to identifying causal pyrolysis practices (e.g. retention times, cooling rates, flow rates, temperature uniformity, etc.,).

The large variation in plant responses to biochar between tropical, temperate, and boreal systems may be partially due to phytotoxicity. Low growth responses to biochar in temperate systems in particular may be further hindered by nutrient immobilization by biochar (Kloss et al. 2014). We speculate that phytotoxicity responses in tropical systems treated with biochar may be reduced due to high soil turnover, rainfall, and/or microbial activity, partially explaining 
460 comparatively higher growth responses in these systems. In boreal systems, with low soil

461 turnover and frequent fires, plants have likely adapted to mobile organic compounds associated

462 with biochar (Jefferey et al. 2011; Thomas \& Gale 2015).

463

464 Convection heating and water leaching biochars mitigated the negative effects of 465 applying biochar to a cambisolic soil (Table 4). Recent studies demonstrate similar effectiveness 466 of leaching and thermal treatment to alleviate inhibition from hardwood, corn, and switchgrass 467 biochars in Rogovska et al., (2012), and in elephant grass and willow biochars in Koltowski \& 468 Oleszczuk, (2015). We used high lignin-cellulose wood biochars produced at moderate pyrolysis 469 temperatures $\left(400-545^{\circ} \mathrm{C}\right)$ at which peak volatilization occurs, likely producing high 470 concentrations of volatile and leachable compounds found here: especially re- condensed bio-oils 471 with a significant aqueous fraction containing phenols and carboxylic acids (Yu et al., 2007;

472 Hale et al., 2012). Higher temperature pyrolysis may generate similar and even greater 473 concentrations of VOCs but may be less prone to re-condensation since cold-spot temperatures 474 are possibly above condensation point.

475

476 Several prior studies have degassed $\left(\right.$ at $>100^{\circ} \mathrm{C}$ ) and water-leached compounds 477 (including ethylene, acetone, benzene, propanol, $\mathrm{K}, \mathrm{Na}, \mathrm{Mg}, \mathrm{Zn}$, etc.) from similar wood 478 biochars (Wu et al., 2011; Novak et al., 2009; Spokas et al., 2011). Indeed, low molecular weight 479 compounds produced during natural fires are volatilized or leached relatively quickly from 480 natural charcoals (Ice, Neary \& Adams, 2004), which may contribute to rapid regeneration 481 following fires (DeLuca, MacKenzie \& Gundale, 2009). Gundale \& Deluca (2007) found 482 positive growth responses in $K$. macrantha when wildfire-produced Douglas Fir and ponderosa 
483 pine biochar was applied, in contrast to growth suppression in un-processed biochar, suggesting

484 weathering of chars alleviates phytotoxic effects of volatile and leachable compounds. It is thus

485 possible that longer heating and leaching times prior to application might have resulted in

486 positive growth responses to biochar in our experiment. Additionally, our biochar was stored in a

487 sealed container prior to the experiment. Strong ventilation or aeration of chars while in storage

488 may have prevented phytotoxicity.

489

490

\section{Leached compounds from biochar inhibit plant growth}

491

492

Effluent from biochars leached with de-ionized water decreased ryegrass growth by up to

$40 \%$ (Table 4), similar to the decreases in growth shown by treatments with the un-processed

494

biochar. This result confirms the growth-inhibitory nature of the aqueous fraction of pyrolysis-

495

produced bio-oils and is consistent with others that have found inhibitory effects from biochar-

496

leached chemical compounds on plant germination (Rogovska et al., 2012; Buss \& Mašek, 2014;

497

Kołtowski \& Oleszczuk, 2015) and microbial communities (Lehmann et al. 2011). Here we

498

report inhibition in a variety of performance traits, rather than germination, from less intense

499

leachings than in (Rogovska et al., 2012), and from more typical neutral to basic chars $(\mathrm{pH}=6.5$

- 7.4) than the acidic char studied by Buss \& Mašek (2014) $(\mathrm{pH}=3.64)$. Since we observed a

501

positive relationship between leaching duration and compound concentration, we recommend

502 that future applications of biochar use pyrolysis post-treatments that leach for longer durations.

503 We watered our plants semi-daily to saturation, potentially leaching compounds quicker than

504 would occur naturally. Phytotoxicity to biochar in areas of low rainfall, or otherwise under

505 growth conditions with low watering frequency might indeed be greater. 
Feedstock characteristics and the conditions of pyrolysis strongly influence the type and

508

509

510

511

512

513

514

515

516

517

518

519

520

521

522

\section{3}

524

525

526

527

528

amount of mobile organic compounds from biochars (Quilliam et al., 2013; Hale et al., 2012), and subsequently, the toxicity of leachates is likely to also be related to system conditions, in particular soil characteristics and microbial composition. Spokas et al., (2011) report lower concentrations of volatile organic compounds in biochars produced from open-pit, kiln, slow, and steam activated pyrolysis compared to those produced via gasification and fast pyrolysis.

Mobile organic compounds in aqueous leachates from poultry litter, but not corn stalk biochars, resulted in germination inhibition of cress seeds (Lepidium sativum) in Rombola et al., (2015). Indeed, spruce and maple charcoals had different volatile matter content and compositions of mobile organic compounds in our study. The effects of mobile organic compounds on soil microorganisms will further influence plant responses (Dutta et al. 2016), with recent research showing shifts in microbial communities from biochar are influenced by soil properties (Noyce et al. 2015). Soil physical and chemical properties such as porosity, aeration, leachability, moisture content, and $\mathrm{pH}$ are also likely to play a critical role in determining hormetic effects of leached mobile organic compounds from biochar, and should be the focus of much further study.

\section{Qualification of phytotoxic compounds and the potential for hormesis}

The increasingly reported null and neutral responses to biochar necessitates quick and reliable analysis of the compounds responsible. SPME-GC-MS promises to serve this role and is becoming the standard for qualification and even semi-quantification of volatile and leachable organic compounds in biochar (Spokas et al., 2011; Buss et al., 2015; Rombolà et al., 2015). We 
529 detected similar low molecular weight compounds to Rombolà et al., (2015) and Buss et al.,

530 (2015) with slight differences in GC-MS phases and procedures. However, we were unable to

531 analyze the other maple biochar produced in a different pyrolysis unit and slightly different

532 feedstock composition for mobile compounds, which potentially limits the array of compounds

533 detected, as well as inference on the influence of pyrolysis conditions on the formation of mobile

534 organic compounds. Buss et al., (2015) report concentrations of phenols and organic acids from

535 moderate temperature pyrolysis of softwood chars in concentrations slightly lower $\left(\sim 22.4 \mathrm{mgL}^{-1}\right.$

536 and $\sim 52.2 \mathrm{mgL}^{-1}$, respectively) than concentrations that have inhibited root elongation in prior

537 studies (Lynch, 1980; Feng et al., 1996).

538

539 Pyroligneous acids, or "wood vinegars", have promoted plant growth and establishment

540 in several studies (Kadota, Hirano \& Imizu, 2002; Du et al., 1998). Acetic acid is the primary

541 component of the chemical fraction in wood vinegars which have a long history of use as plant

542 growth stimulators (Mu, Uehara \& Furuno, 2004; Mungkunkamchao et al., 2013). Mu, Uehara \&

543 Furuno (2003) showed strong hormetic responses in seed germination of four species: Lactuca

544 sativa, Rorippa nasturtium-aquaticum, Cryptotaenia japonica, Chrysanthemum corronarium.

545 Strong inhibition of germination and radical growth was observed at high concentrations, while

546 dilutions stimulated germination and growth, with obvious species-specific responses. Root

547 development was increased, but not shoot development, when diluted wood vinegar was added

548 to Pyrus pyrifolia cuttings (Kadota, Hirano \& Imizu, 2002). Similarly, radicle length was

549 increased when aqueous extracts of one of several charcoals was added to corn seeds in

550 Rogovska et al., (2012). Accurate quantification of volatile and leachable organic compounds in

551 biochar is necessary to determine the type of hormetic plant responses; however, current SPME- 
552 GC-MS techniques offer only semi-quantification with noted difficulties (Spokas et al., 2011;

553 Dutta et al. 2016). Germination tests could be utilized to evaluate hormetic effects from mobile

554 organic compounds in biochar: principally, to identify compounds responsible, possible

555 synergistic effects, and species-specific toxicity thresholds.

556

557 Conclusions

558

559

In summary, the negative and null responses of two common forage crop species,

560 ryegrass and clover, to biochar additions were contrary to overall trend of positive plant growth

561 responses presented in recent meta-analyses (Jeffery et al., 2011; Liu et al., 2013; Biederman \&

562 Harpole, 2013; Thomas \& Gale, 2015). Our results strongly suggest that mobile organic

563 compounds from biochar were responsible for this growth inhibition (primarily organic acids and

564 phenols), as heating and leaching biochar before application alleviated this negative response,

565 and addition of leachates alone replicated the negative responses observed. Chemical analysis of

566 chars and leachates suggest possible specific molecules involved, including acetic acid, butyric

567 acid, bisphenol and benzonoic acid.

568

569

Our results suggest that negative responses to mobile compounds (in plants and soil

570

biota) leached or evolved from biochars are an important mechanism accounting in part for the

571 wide variation in plant growth responses to biochar described in the literature. Progressive

572 volatilization and leaching almost certainly occurs in the field through weathering, both for

573 charcoal produced during forest fires, and biochar applied as a soil amendment. Weathering of

574 biochar will likely lead to rapid reductions in toxicity under field conditions. Additionally, soil

575 flora and fauna likely metabolize mobile organic compounds rapidly further reducing toxicity in 
576 field soils with high soil floral and faunal diversity and abundance. Whether pre-weathering of

577 biochars before application is beneficial (in terms of cost and reduction of negative effects on

578 biota), or if natural weathering is sufficient to quickly remove toxic compounds, are important

579 considerations for future studies and applied use of biochars. Investigations into production and

580 storage methods that remove or decrease concentrations of compounds - such as heating and

581 retention times, and ventilation, respectively - are needed. Efforts to identify the source of

582 contamination of biochar, to accurately quantify toxic volatile and leachable compounds from

583 biochars, and to test their potential toxicity to biota in a variety of systems and applications (i.e.

584 temperate/ tropical agricultural, forestry, environmental remediation, etc.,) are also fundamental

585 to optimize the use of chars as a soil amendment.

586

587 Acknowledgements:

588

589 We thank Haliburton Forest and Wildlife Reserve Ltd, Haliburton, ON for research

590 support and provision of biochars and soil. Special thanks are also due to Chihiro Ikeda, Sossina

591 Gezahegn, Aruna Kumari, Kathleen Manson, Janise Herridge, Carolyn Winsborough,

592 Gowthaman Rajakumar and Katie Ungard for assistance with the experiments, and to Tony

593 Adamo and Robert T. Gale for help with analytic work.

594 


\section{References}

596

597 Asai H, Samson BK, Stephan HM, Songyikhangsuthor K, Homma K, Kiyono Y, Inoue Y, 598 Shiraiwa T, Horie T 2009. Biochar amendment techniques for upland rice production in $599 \quad$ Northern Laos. Field Crops Research 111:81-84.

600

601

ASTM, 1999. Standard Test Method for Particle Size Distribution of Granular Activated Carbon. 602 ASTM Standard D2862-97. Annual Book of ASTM Standards 15: 723 -725.

603

604 605

ASTM, 2007. Standard Test Method for Chemical Analysis of Wood Charcoal. ASTM D1762-

84. ASTM International.

606

607

608

Atkinson CJ, Fitzgerald JD, Hipps NA 2010. Potential mechanisms for achieving agricultural benefits from biochar application to temperate soils: a review. Plant and soil 337:1-18.

609

610

Baldwin IT, Halitschke R, Paschold A, Dahl von CC, Preston CA 2006. Volatile Signaling in

611 Plant-Plant Interactions: "Talking Trees” in the Genomics Era. Science 311:812-815.

612

613 Biederman LA, Harpole WS 2013. Biochar and its effects on plant productivity and nutrient 614 cycling: a meta-analysis. GCB Bioenergy 5:202-214.

615

616 Bilbao R, Millera A, Arauzo J 1989. Thermal decomposition of lignocellulosic materials:

617 influence of the chemical composition. Thermochimica acta 143:149-159. 
618

619 Bretz F, Hothorn T, Westfall P 2002. On multiple comparisons in R. R News 2: 14-17.

620

621 Bretz F, Genz A, Hothorn L 2001. On the numerical availability of multiple comparison 622 procedures. Biometrical Journal 43.5: 645-656.

623

624 Buss W, Mašek O 2014. Mobile organic compounds in biochar - A potential source

625 of contamination - Phytotoxic effects on cress seed (Lepidium sativum) germination.

626 Journal of Environmental Management 137:111-119.

627

628 Buss W, Mašek O, Graham M, Wüst D 2015. Inherent organic compounds in biochar-Their 629 content, composition and potential toxic effects. Journal of Environmental Management

630 156:150-157.

631

632 Calabrese EJ, Iavicoli I, Calabrese V 2012. Hormesis: why it is important to biogerontologists.

633 Biogerontology 13:215-235.

634

635 Deenik JL, McClellan T, Uehara G, Antal MJ, Campbell S 2010. Charcoal volatile matter 636 content influences plant growth and soil nitrogen transformations. Soil Science Society of 637 America Journal 74: 1259-1270.

638

639 DeLuca TH, MacKenzie MD, Gundale MJ 2009. Biochar effects on soil nutrient

640 transformations. Biochar for environmental management: Science and Technology 251-270. 
641

642 Domene X, Enders A, Hanley K, Lehmann J 2015. Ecotoxicological characterization of

643 biochars: Role of feedstock and pyrolysis temperature. Science of The Total Environment

$644 \quad 512-513: 552-561$.

645

646 Du HG, Mori E, Terao H, Tsuzui 1998. Effect of the mixture of charcoal with pyroligneous acid 647 on shoot and root growth of sweet potato. Japanese Journal of Crop Science 67: 149 - 152.

648

649 Dutta T, Kwon E, Bhattacharya SS, Jeon BH, Uchimiya M, Kim KH 2016. Polycyclic aromatic 650 hydrocarbons and volatile organic compounds in biochar-amended soil: a review. $G C B$ 651 Bioenergy 10.1111/gcbb.12363.

652

653 Feng L, Wang LS, Zhao YH, Song B 1996. Effects of substituted anilines and phenols on root 654 elongation of cabbage seed. Chemosphere 32:1575-1583.

655

656 Fulton W, Gray M, Prahl F, Kleber M 2013. A simple technique to eliminate ethylene emissions 657 from biochar amendment in agriculture. Agronomy for sustainable development 33:469-474.

658

659 Garbutt K, Bazzaz FA 1987. Population niche structure: Differential response of Abutilon 660 theophrasti progeny to resource gradients. Oecologia 72: 291-296.

661

662 Glaser B, Lehmann J, Zech W 2002. Ameliorating physical and chemical properties of highly 663 weathered soils in the tropics with charcoal - a review. Biology and Fertility of Soils 35:219- 
665

666 Graber ER, Harel YM, Kolton M, Cytryn E, et al 2010. Biochar impact on development and 667 productivity of pepper and tomato grown in fertigated soilless media. Plant and Soil 337: 481668496.

669

670 Gundale MJ, DeLuca TH 2007. Charcoal effects on soil solution chemistry and growth of 671 Koeleria macrantha in the ponderosa pine/Douglas-fir ecosystem. Biology and Fertility of 672 Soils 43: 303-311.

673

674 Hale SE, Lehmann J, Rutherford D, Zimmerman AR, Bachmann RT, Shitumbanuma V, O’Toole 675 A, Sundqvist KL, Arp HPH, Cornelissen G 2012. Quantifying the Total and Bioavailable 676 Polycyclic Aromatic Hydrocarbons and Dioxins in Biochars. Environmental Science \& 677 Technology 46:2830-2838.

678

679

Hajaligol M, Waymack B, Kellogg D 2001. Low temperature formation of aromatic hydrocarbon 680 from pyrolysis of cellulosic materials. Fuel 80:1799-1807.

681

682 Hothorn T, Bretz F, Westfall P, Heiberger RM, Schuetzenmeister A 2008. Multcomp:

683 simultaneous inference in general parametric models. $R$ package version 1-3

684

685 Ice G, Neary D, Adams PW 2004. Effects of wildfire on soils and watershed processes. Journal 686 of Forestry 102.6: 16-20. 
687

688 Jeffery S, Verheijen FGA, Van Der Velde M, Bastos AC 2011. A quantitative review of the

689 effects of biochar application to soils on crop productivity using meta-analysis. Agriculture,

$690 \quad$ Ecosystems \& Environment 144:175-187.

691

692 Jonker MT, Koelmans AA 2002. Extraction of polycyclic aromatic hydrocarbons from soot and 693 sediment: Solvent evaluation and implications for sorption mechanism. Environmental Science 694 and Technology 36: 4107- 4113.

695

696

697

Kadota M, Hirano T, Imizu 2002. Pyroligneous acid improves in-vitro rooting of Japanese pear cultivars. Horticultural Science 37: 194 -195.

698

699 Keeley SC, Keeley JE, Hutchinson SM, Johnson AW 1981. Postfire succession of the 700 herbaceous flora in southern California chaparral. Ecology 62: 1608-1621.

701

702

Kloss S, Zehetner F, Dellantonio A, Hamid R, Ottner F, Liedtke V, Schwanninger M, Gerzabek

703

704

705 1000.

706

707 Kloss S, Zehetner F, Wimmer B, Buecker J, Rempt F, Soja G 2014b. Biochar application to 708 temperate soils: Effects on soil fertility and crop growth under greenhouse conditions. Journal of Plant Nutrition and Soil Science 177:3-15. 
711 Kołtowski M, Oleszczuk P 2015. Toxicity of biochars after polycyclic aromatic hydrocarbons 712 removal by thermal treatment. Ecological Engineering 75:79-85.

713

714 Lashari MS, Liu Y, Li L, Pan W, Fu J, Pan G, Zheng J, Zheng J, Zhang X, Yu X 2013. Effects of 715 amendment of biochar-manure compost in conjunction with pyroligneous solution on soil 716 quality and wheat yield of a salt-stressed cropland from Central China Great Plain. Field $717 \quad$ Crops Research 144:113-118.

718

719 Ledgard SF, Steele KW 1992. Biological nitrogen fixation in mixed legume/grass pastures. In: 720 Biological Nitrogen Fixation for Sustainable Agriculture. Dordrecht: Springer Netherlands, 721 $137-153$.

722

723

Lehmann J 2007. A handful of carbon. Nature 447:143-144.

724

725 Lehmann J, Rillig MC, Thies J, Masiello CA, Hockaday WC, Crowley D 2011. Biochar effects 726 on soil biota-a review. Soil Biology and Biochemistry 43: 1812-1836.

727

728

Lievens C, Mourant D, Gunawan R, Hu X, Wang Y 2015. Organic compounds leached from fast 729 pyrolysis mallee leaf and bark biochars. Chemosphere 139:659-664.

730

731

Liu X, Zhang A, Ji C, Joseph S, Bian R, Li L, Pan G, Paz-Ferreiro J 2013. Biochar's effect on 732 crop productivity and the dependence on experimental conditions - a meta-analysis of 
literature data. Plant and soil 373:583-594.

734

735

736

Lucchini P, Quilliam RS, DeLuca TH, Vamerali T, Jones DL 2014. Does biochar application 737 alter heavy metal dynamics in agricultural soil? Agriculture, Ecosystems \& Environment

737 184:149-157.

738

739

740

Lynch JM 1980. Effects of organic acids on the germination of seeds and growth of seedlings. Plant, Cell, \& Environment 3: 255-259.

741

742

743

Major J, Rondon M, Molina D, Riha SJ, Lehmann J 2010. Maize yield and nutrition during 4 years after biochar application to a Colombian savanna oxisol. Plant and soil 333:117-

744 128.

745

746

747

748

Makoto K, Choi D, Hashidoko Y, Koike T 2011. The growth of Larix gmelinii seedlings as affected by charcoal produced at two different temperatures. Biology and Fertility of Soils

749

750

Marks EAN, Alcañiz JM, Domene X 2014. Unintended effects of biochars on short-term plant 751 growth in a calcareous soil. Plant and soil 385:87-105.

752

753

Milberg P 1995. Soil Seed Bank after Eighteen Years of Succession from Grassland to Forest. 754 Oikos 72:3.

755 
756 Morrison IM 1972. A semi-micro method for the determination of lignin and its use in predicting 757 the digestibility of forage crops. Journal of the Science of Food and Agriculture 23: 455-463.

758

759

760

761

762

763

764

765

766

767

768

769

770

771

772

773

774

775

776

777

778

Mu J, Uehara T, Furuno T 2003. Effect of bamboo vinegar on regulation of germination and radicle growth of seed plants. Journal of Wood Science 49:262-270.

Mu J, Uehara T, Furuno T 2004. Effect of bamboo vinegar on regulation of germination and radicle growth of seed plants II: composition of moso bamboo vinegar at different collection temperature and its effects. Journal of Wood Science 50:470-476.

Mukherjee A, Zimmerman AR 2013. Organic carbon and nutrient release from a range of laboratory-produced biochars and biochar-soil mixtures. Geoderma 193-194:122-130.

Mungkunkamchao T, Kesmala T, Pimratch S, Toomsan B, Jothityangkoon D 2013. Wood vinegar and fermented bioextracts: Natural products to enhance growth and yield of tomato (Solanum lycopersicum L.). Scientia Horticulturae 154:66-72.

Novak JM, Busscher WJ, Laird DL, Ahmedna M, Watts DW, Niandou MAS 2009. Impact of Biochar Amendment on Fertility of a Southeastern Coastal Plain Soil. Soil Science 174:105112.

Novak JM, Cantrell KB, Watts DW, Busscher WJ, Johnson MG 2014. Designing relevant biochars as soil amendments using lignocellulosic-based and manure-based feedstocks. 
779

780

781

782

783

784

785

786

787

788

789

790

791

792

793

794

795

796

797

798

799

800

801

Journal of Soils and Sediments 14:330-343.

Ortega-Martínez O, Pernas M, Carol RJ, Dolan L 2007. Ethylene Modulates Stem Cell Division in the Arabidopsis thaliana Root. Science 317:507-510.

Park JH, Choppala GK, Bolan NS, Chung JW, Chuasavathi T 2011. Biochar reduces the bioavailability and phytotoxicity of heavy metals. Plant and soil 348:439-451.

Pettersen RC 1984. The chemical composition of wood. Rowell RM (ed.), The chemistry of solid wood, pp 57-126. American Chemical Society, Washington, DC, USA.

Pluchon N, Gundale MJ, Nilsson M-C, Kardol P, Wardle DA 2014. Stimulation of boreal tree seedling growth by wood-derived charcoal: effects of charcoal properties, seedling species and soil fertility. Functional Ecology 28:766-775.

Quilliam RS, DeLuca TH, Jones DL 2012. Biochar application reduces nodulation but increases nitrogenase activity in clover. Plant and soil 366:83-92.

Quilliam RS, Rangecroft S, Emmett BA, Deluca TH, Jones DL 2013. Is biochar a source or sink for polycyclic aromatic hydrocarbon (PAH) compounds in agricultural soils? $G C B$ Bioenergy 5: 96-103. 
802 R Core Team (2012) R: A language and environment for statistical computing. Vienna, Austria. 803

804 Rajkovich S, Enders A, Hanley K, Hyland C, Zimmerman AR, Lehmann J 2012. Corn growth 805 and nitrogen nutrition after additions of biochars with varying properties to a temperate soil. 806 Biology and Fertility of Soils 48: 271-284.

807

808 Rogovska N, Laird D, Cruse RM, Trabue S, Heaton E 2012. Germination Tests for Assessing 809 Biochar Quality. Journal of Environmental Quality 41:1014-1022.

810

811 Rombolà AG, Marisi G, Torri C, Fabbri D, Buscaroli A, Ghidotti M, Hornung A 2015.

812 Relationships between Chemical Characteristics and Phytotoxicity of Biochar from Poultry 813 Litter Pyrolysis. Journal of Agricultural and Food Chemistry 63:6660-6667.

814

815 Rondon MA, Lehmann J, Ramírez J, Hurtado M 2007. Biological nitrogen fixation by common 816 beans (Phaseolus vulgaris L.) increases with bio-char additions. Biology and Fertility of Soils $817 \quad 43: 699-708$.

818

819 Sackett TE, Basiliko N, Noyce GL, Winsborough C, Schurman J, Ikeda C, Thomas SC 2015. 820 Soil and greenhouse gas responses to biochar additions in a temperate hardwood forest. GCB 821 Bioenergy 7:1062-1074.

822

823 Schaarschmidt F, Vaas L 2009. Analysis of trials with complex treatment structure using 824 multiple contrast tests. Horticultural Science 44.1: 188-195. 
825

826 Shafizadeh F 1982. Introduction to pyrolysis of biomass. Journal of Analytical and Applied

827 Pyrolysis 3:283-305.

828

829 Soil Classification Working Group. 1998. The Canadian System of Soil Classification, 3rd ed. 830 Agriculture and Agri-Food Canada Publication 1646: 187 pp. ISBN 0-660-17404-9

831

832 Spokas KA 2013. Impact of biochar field aging on laboratory greenhouse gas production 833 potentials. GCB Bioenergy 5:165-176.

834

835 Spokas KA, Baker JM, Reicosky DC 2010. Ethylene: potential key for biochar amendment 836 impacts. Plant and soil 333:443-452.

837

838 Spokas KA, Cantrell KB, Novak JM, Archer DW, Ippolito JA, Collins HP, Boateng AA, Lima

839 IM, Lamb MC, McAloon AJ, Lentz RD, Nichols KA 2012. Biochar: A Synthesis of Its $840 \quad$ Agronomic Impact beyond Carbon Sequestration. Journal of Environmental Quality 41:973841989.

842

843 Spokas KA, Novak JM, Stewart CE, Cantrell KB, Uchimiya M, DuSaire MG, Ro KS 2011.

844 Qualitative analysis of volatile organic compounds on biochar. Chemosphere 85:869-882.

845

846 Thomas SC, Gale N 2015. Biochar and forest restoration: a review and meta-analysis of tree 847 growth responses. New Forests 46:931-946. 
848

849 Thomas SC, Frye S, Gale N, Garmon M, Launchbury R, Machado N, Melamed S, Murray J,

850 Petroff A, Winsborough C 2013. Biochar mitigates negative effects of salt additions on two

851 herbaceous plant species. Journal of Environmental Management 129:62-68.

852

853 Velmurugan N, Han SS, Lee YS 2009. Antifungal Activity of Neutralized Wood Vinegar with

$854 \quad$ Water Extracts of Pinus densiflora and Quercus serrata $\quad$ Saw Dusts. International

$855 \quad$ Journal of Environmental Resources 3: 167 - 176.

856

857 Wardle DA, Zackrisson O, Nilsson MC 1998. The charcoal effect in Boreal forests: mechanisms 858 and ecological consequences. Oecologia 115:419-426.

859

860 Welsch-Pausch K, McLachlan MS, Umlauf G 2002. Determination of the Principal Pathways of 861 Polychlorinated Dibenzo-p-dioxins and Dibenzofurans to Lolium multiflorum (Welsh Ray 862 Grass). Environmental Science \& Technology 29:1090-1098.

863

864 Wu H, Yip K, Kong Z, Li CZ, Liu D, Yu Y, Gao X 2011. Removal and recycling of inherent 865 inorganic nutrient species in mallee biomass and derived biochars by water leaching. Industrial 866 \& Engineering Chemistry Research 50: 12143-12151.

867

868 Yatagai M, Nishimoto M, Hori K, Ohira T, Shibata A 2002. Termiticidal activity of wood

869 vinegar, its components and their homologues. Journal of Wood Science 48:338-342.

870 
871 Yu F, Deng S, Chen P, Liu Y, Wan Y, Olson A, Kittelson D, Ruan R 2007. Physical and

872 chemical properties of bio-oils from microwave pyrolysis of corn stover. Applied

873 Biochemistry and Biotechnology 137-140:957-970.

874

875

876

877

878

879 


\section{Figure 1}

Ryegrass growth responses to fresh biochars: contrasts between treatments

Fig 1 Simultaneous confidence intervals (95\%) for aboveground biomass (a), belowground biomass (b), leaf area (c) of ryegrass to biochar type (MB, SB, MFT), addition rate $(5,10,20$ t/ha), and application method (Mixed or Top dressing (Top)) (Experiment 1). Significant differences between treatment means are denoted with asterisks $(P=<0.05 *,<0.01 * *$, $\left.0.001^{* * *}\right)$.
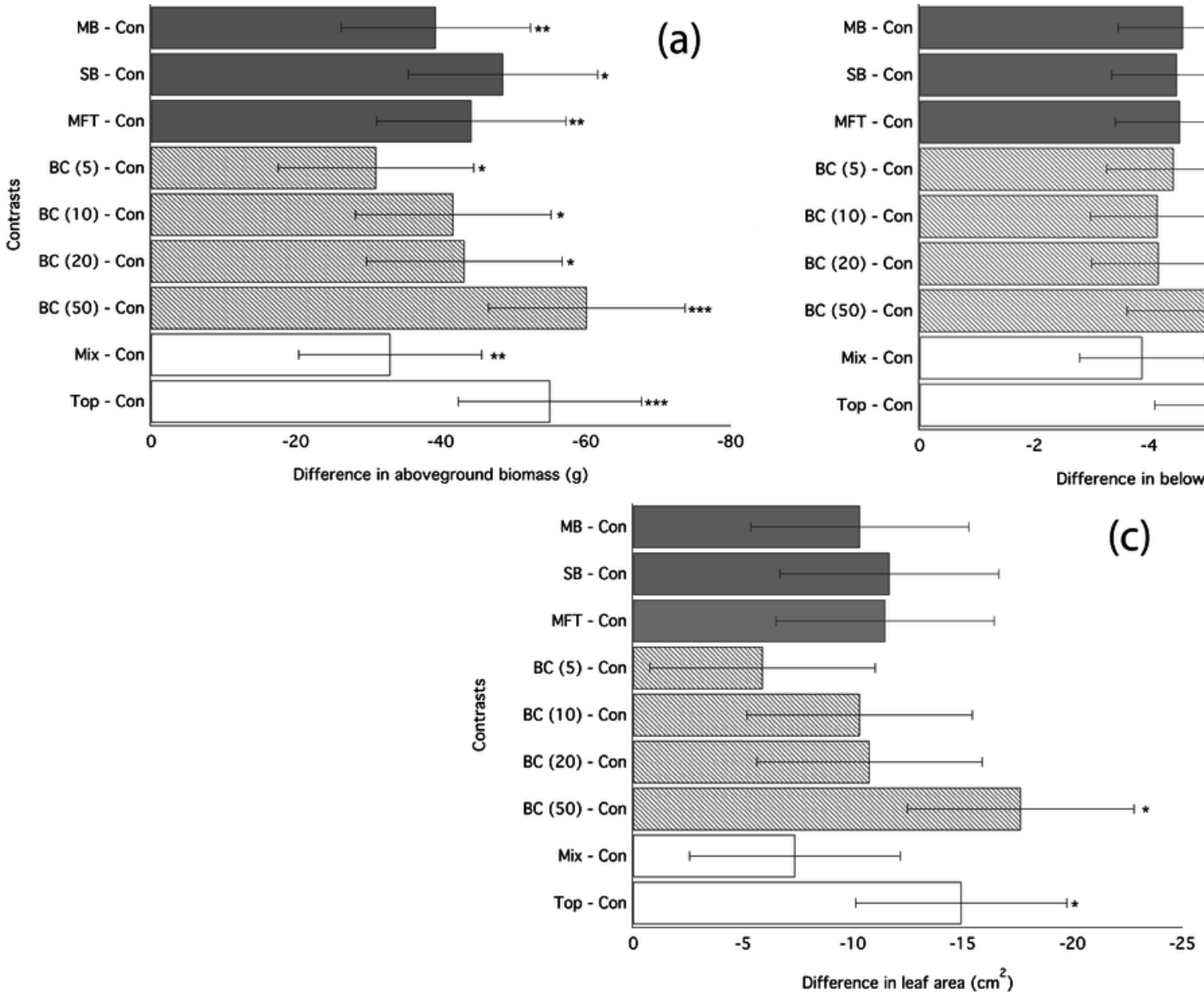

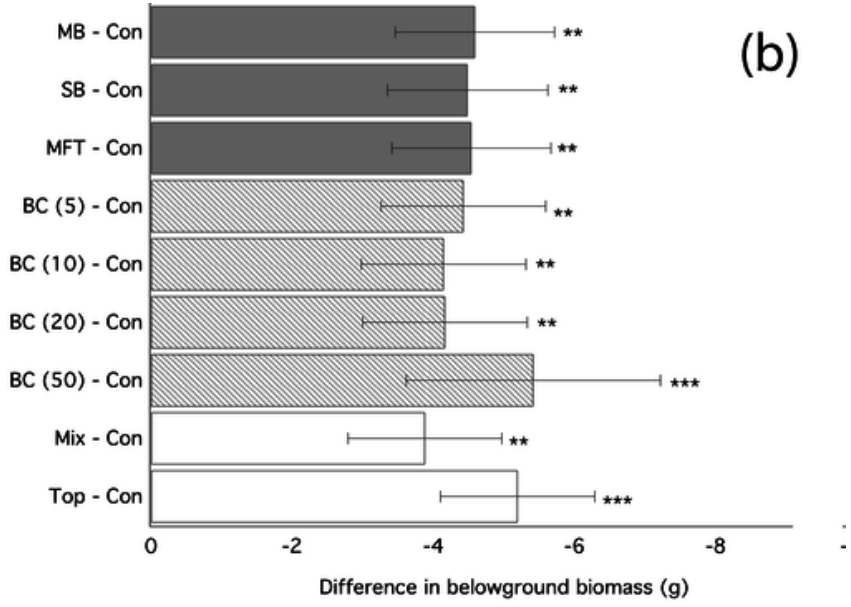

(c) 


\section{Figure 2}

Ryegrass growth response effect size as a function of biochar addition rate

Fig 2 The relative effect size (response ratio - RR) of biochar treatment for aboveground biomass (a), belowground biomass (b), and leaf area (c) of ryegrass, as a function of biochar addition rate. Effect size is calculated as $R R=\ln (B / C)$, where $B$ is mean response of the biochar treated plants, and $\mathrm{C}$ is the mean response of the non-biochar treated control plants. Regressions were performed for each biochar type (MB, SB, MFT); significant linear relationships are denoted with asterisks $(P=<0.05 *,<0.01 * *, 0.001 * * *)$. 

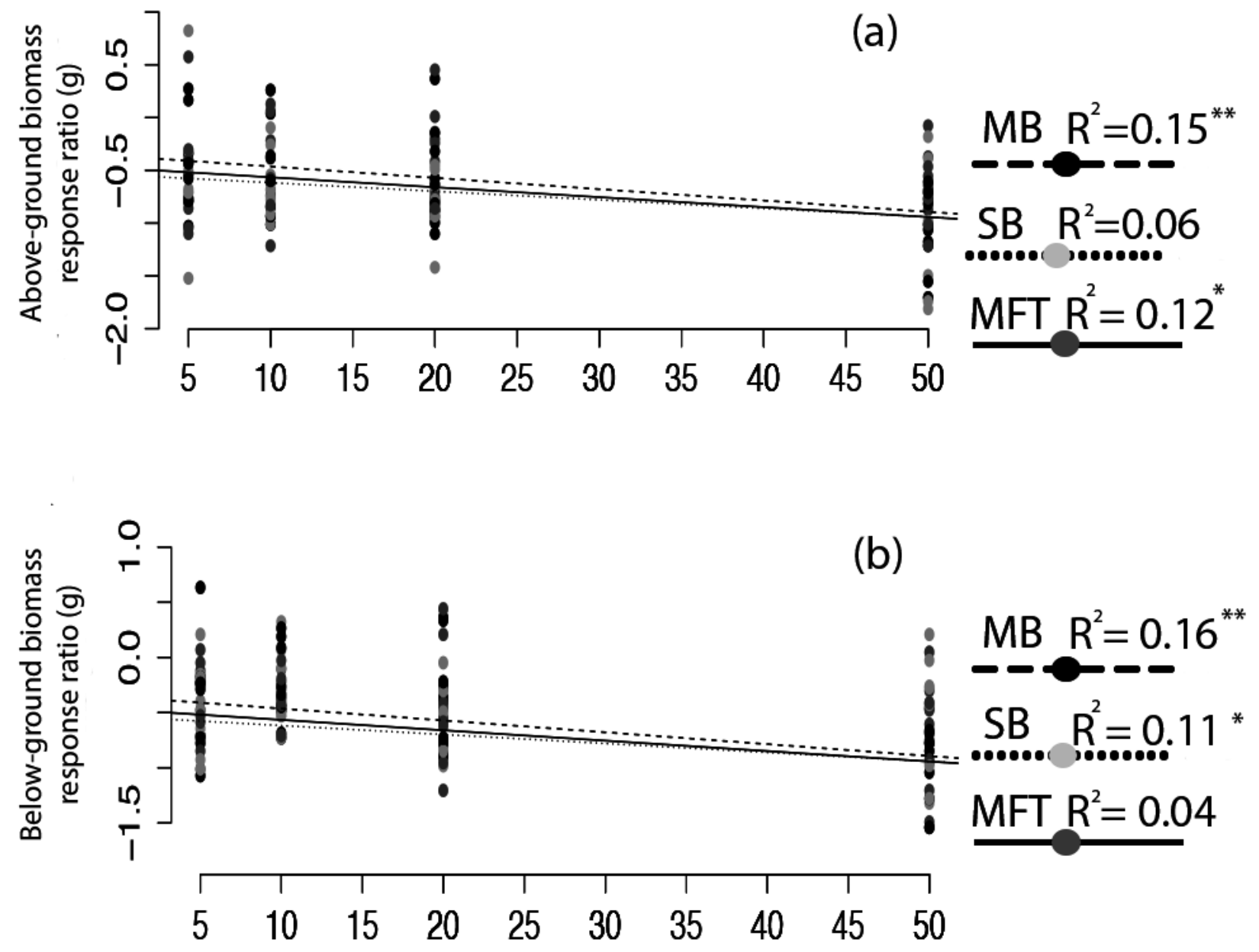

(c)

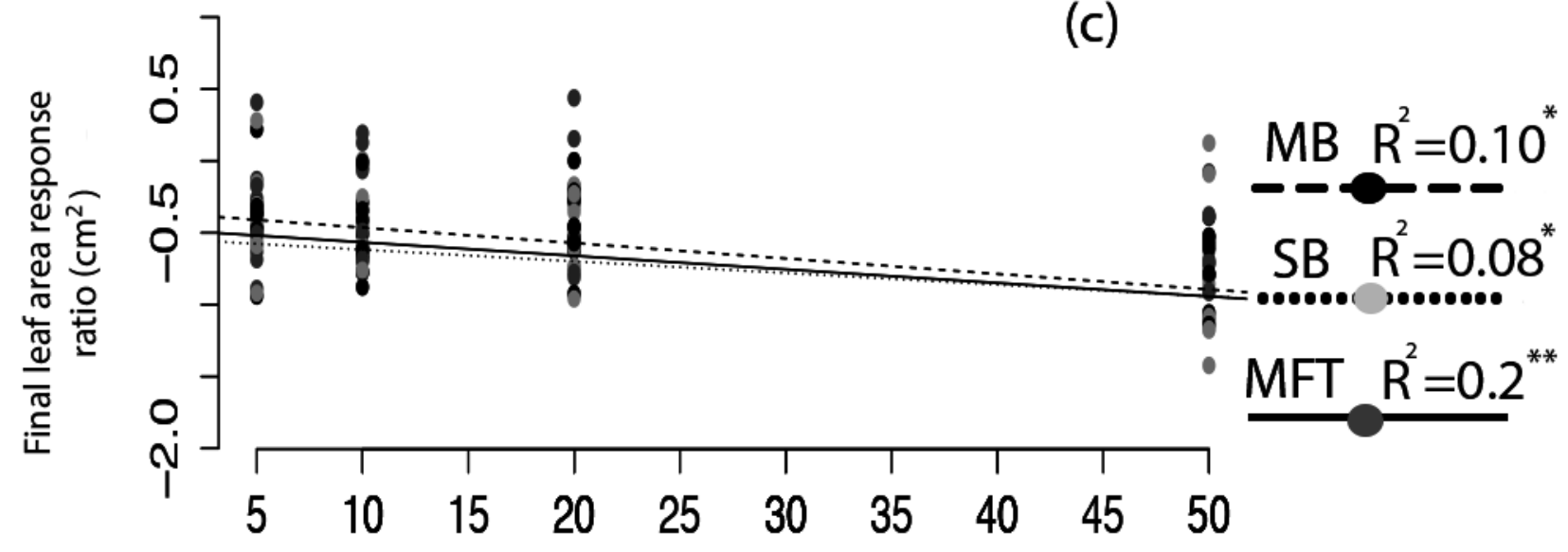

Biochar addition rate $(\mathrm{t} / \mathrm{ha})$ 
Figure 3

Ryegrass growth responses to thermally treated and leached chars: contrasts between treatments

Fig 3 Simultaneous confidence intervals (95\%) for ryegrass aboveground biomass (a) and belowground biomass (b) responses to water washed (striped bars) and convection heated (grey bars) biochar (Experiment 2). BC = biochar (unwashed); BC (Mix)=biochar, mixed; BC (Top)=biochar, top-dressing. Abbreviations for heating (Heat) and washing (WW) treatments are defined in the methods. Significant differences between treatment means are denoted with asterisks $(P=<0.05 *,<0.01 * *, 0.001 * * *)$.
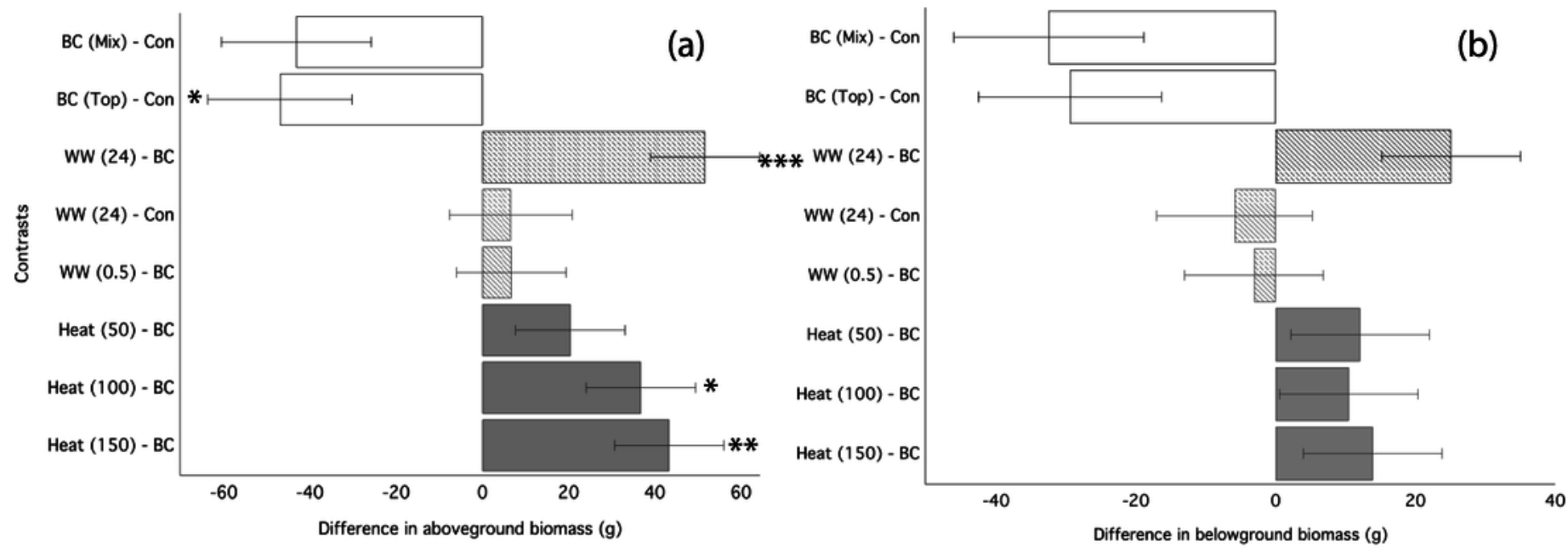


\section{Figure 4}

Ryegrass growth responses to leachates from water washed chars

Fig 4 Simultaneous confidence intervals (95\%) for ryegrass aboveground biomass (a), belowground biomass (b), and leaf area (c) response in Experiment 2 to dissolved compounds from water-washed biochar leachates (Leach) applied as a $5 \mathrm{~mL}$ single dose following germination. Leachate treatments are defined in the methods. Significant differences between treatment means are denoted with asterisks $(P=<0.05 *,<0.01 * *$, $\left.0.001^{* * *}\right)$.
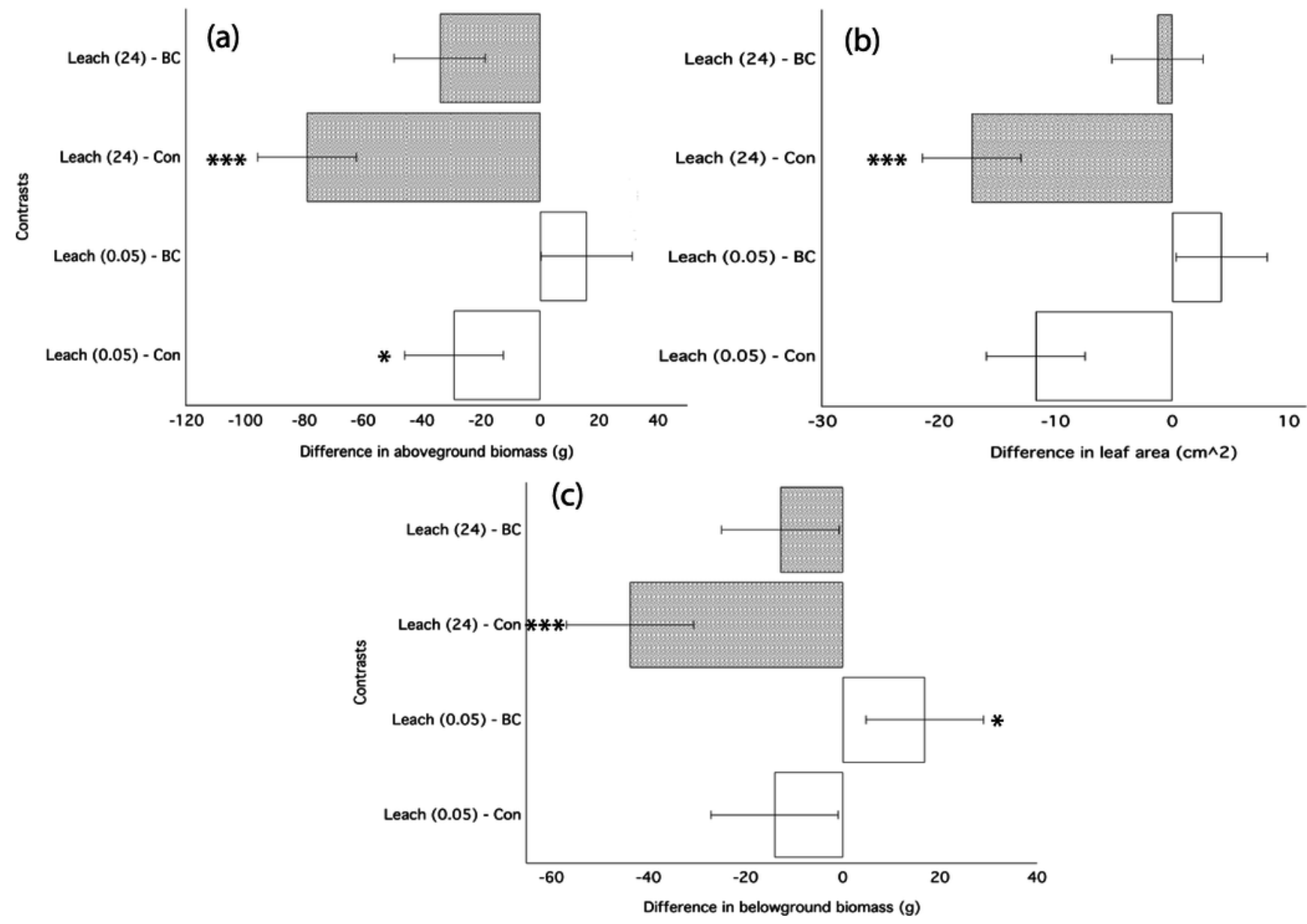
Figure 5

Ion chromatograms of SPME on biochars and leachates

Fig 5 Total ion chromatograms of HS-SPME of maple (A) and spruce (B) biochar, and DI-SPME of maple (C) and spruce (D) water leachates.
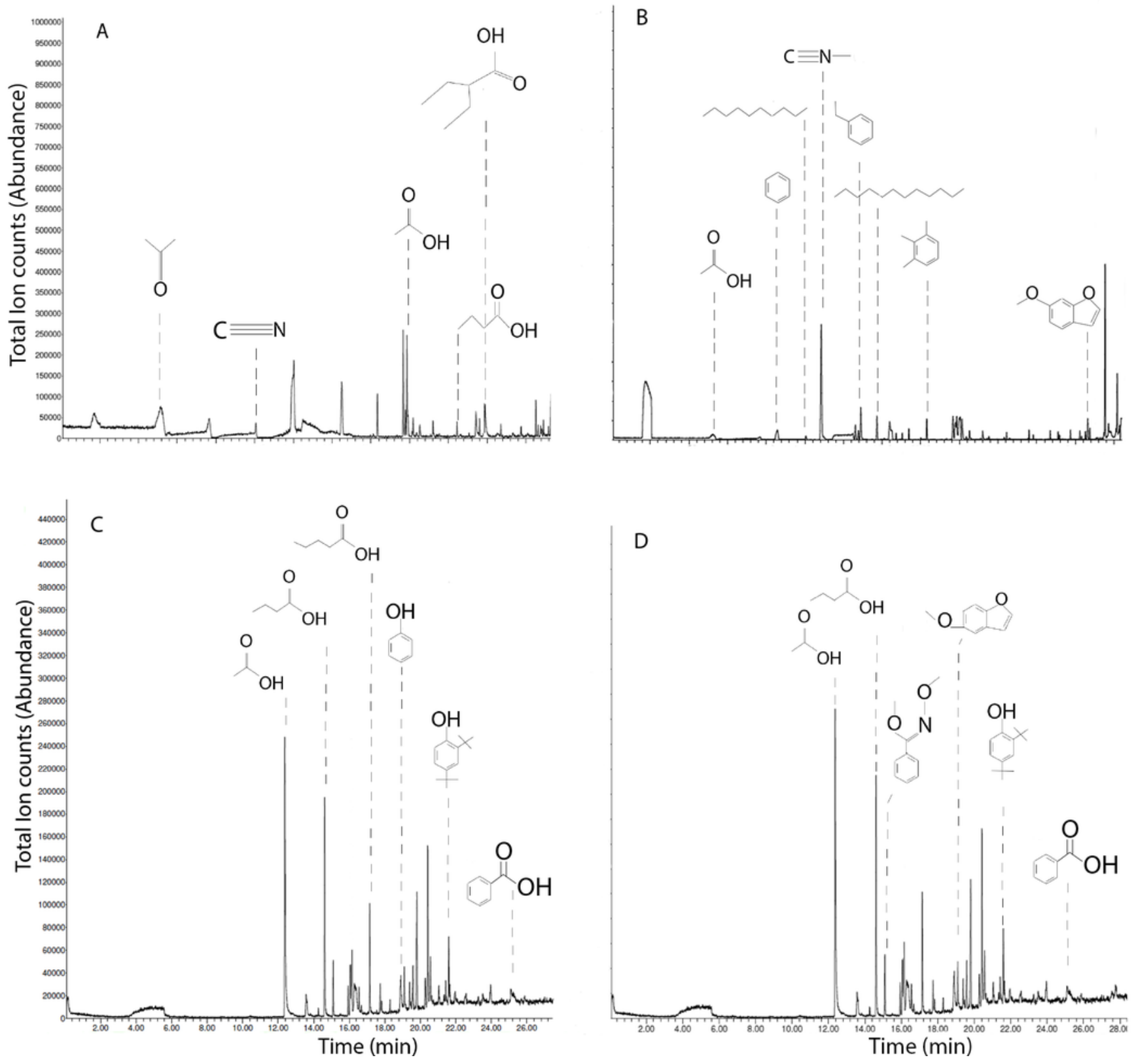


\section{Table $\mathbf{1}$ (on next page)}

Physical and chemical properties of biochars

Table 1. Properties of maple and spruce sawdust biochar made in an $80 \mathrm{~L}$ batch pyrolyzer with highest treatment temperature between $350-450{ }^{\circ} \mathrm{C}$ (from Sackett et al. (2015)), and maple / birch sawdust biochar produced in a flow-through screw fed pyrolyzer with highest treatment temperature of $500-600^{\circ} \mathrm{C}$. Three replicates were used for each characterization. Values not determined are abbreviated as n/a (not applicable) 


\section{Attribute}

Moisture (\%)

Ash (\%)

Volatile matter (\%)

Fixed carbon (\%)

$\mathrm{pH}$

$\mathrm{EC}(\mu \mathrm{S} / \mathrm{cm})$

Elemental composition

C (\%)

$\mathrm{N}(\%)$

$\mathrm{S}(\%)$

Phosphorous ( $\mathrm{mg} / \mathrm{kg}$ )

$\mathrm{Ca}(\mathrm{mg} / \mathrm{kg})$

$\mathrm{K}(\mathrm{mg} / \mathrm{kg})$

$\mathrm{Mg}(\mathrm{mg} / \mathrm{kg})$

Particle size distribution

$>4000 \mu \mathrm{m}(\%)$

$2000-4000 \mu \mathrm{m}(\%)$

$500-2000 \mu \mathrm{m}(\%)$

$250-500 \mu \mathrm{m}(\%)$

$125-250 \mu \mathrm{m}(\%)$

$125-63 \mu \mathrm{m}(\%)$

$<63 \mu \mathrm{m}(\%)$

Maple Flow Through BC
$2.7(0.0)$
$2.74(0.06)$
$29.87(3.07)$
$64.68(3.07)$
$7.39(0.23)$
$105(4)$

$85.01(2.3)$

0.71

$\mathrm{n} / \mathrm{a}$

$\mathrm{n} / \mathrm{a}$

$\mathrm{n} / \mathrm{a}$

$\mathrm{n} / \mathrm{a}$

$\mathrm{n} / \mathrm{a}$

$0.76(0.95)$

$15.37(1.52)$

$57.25(2.63)$

$13.49(0.84)$

$9.18(2.42)$

$3.63(1.48)$

$0.30(0.15)$

\author{
Maple Batch BC \\ $2.43(0.15)$ \\ $1.67(0.06)$ \\ $29.64(2.64)$ \\ $66.25(2.64)$ \\ $7.7(0.50)$ \\ 75 (10)
}

$77.3(3)$

$0.10(0.01)$

$0.02(0.0)$

197 (16)

6015 (944)

3443 (105)

619 (6)

$0.40(0.11)$

$5.61(0.91)$

$31.53(2.54)$

$27.74(2.43)$

$25.32(0.74)$

$9.02(0.36)$

$0.39(0.16)$
Spruce Batch BC

$2.4(0.100)$

$0.65(0.06)$

$21.38(0.32)$

$75.57(0.32)$

$6.5(0.0)$

$72(14)$

77.9

0.01

0.01

75

2419

1243

285

$3.09(1.91)$

$17.39(0.98)$

$59.14(0.89)$

$11.44(.227)$

$7.05(0.59)$

$1.85(0.31)$

$0.01(0.02)$ 


\section{Table 2 (on next page)}

Soil physical and chemical properties

Table 2. Properties of the drystic cambisol soil used in both experiments collected from the uppermost mineral layer in a temperate forest, Haliburton ON. Soil analysis was done at the Agriculture and Food Laboratory, University of Guelph, Guelph, ON. Test procedures and units are reported in parenthesis. Three replicates were used for all analyses. 


\begin{tabular}{|lc|}
\hline Attribute & Value \\
moisture (\%) & 2.72 \\
organic matter (\%) & 12.3 \\
$\mathrm{NH}_{4}\left(\mathrm{KCl}-\mathrm{NH}_{4}, \mathrm{mg} / \mathrm{kg}\right)$ & 3.8 \\
$\mathrm{NO}_{3}-\mathrm{N}\left(\mathrm{KCl}-\mathrm{NH}_{4}, \mathrm{mg} / \mathrm{kg}\right)$ & 148 \\
$\mathrm{P}\left(\mathrm{NaHCO}_{3}, \mathrm{mg} / \mathrm{L}\right)$ & 32 \\
$\mathrm{Mg}\left(\mathrm{NH}_{4} \mathrm{C}_{2} \mathrm{H}_{3} \mathrm{O}_{2}, \mathrm{mg} / \mathrm{L}\right)$ & 140 \\
$\mathrm{~K}\left(\mathrm{NH}_{4} \mathrm{C}_{2} \mathrm{H}_{3} \mathrm{O}_{2}, \mathrm{mg} / \mathrm{L}\right)$ & 62 \\
$\mathrm{pH}\left(\mathrm{CaCl}_{2}\right)$ & 6.8 \\
\hline
\end{tabular}

2 


\section{Table 3 (on next page)}

Mean growth responses values for clover and ryegrass

Table 3. Mean values for aboveground biomass ( $\mathrm{g}$ ), belowground biomass ( $\mathrm{g}$ ), and leaf area $\left(\mathrm{cm}^{2}\right)$ for ryegrass and clover grown in treatments with maple and spruce sawdust biochar made in an $80 \mathrm{~L}$ batch pyrolyzer with highest treatment temperature between $350-450{ }^{\circ} \mathrm{C}$, and in treatments with maple / birch sawdust biochar produced in a flow-through screw fed pyrolyzer with highest treatment temperature of $500-600^{\circ} \mathrm{C}$ (Experiment 1 ). "BC (dosage)" is the mean value for all treatments of biochar at that dose, and "BC mixed/ top-dressing" is the mean values for all biochar treatments applied as mixed and top-dressings. 


\begin{tabular}{|lcc|cc|ccc|}
\hline \multirow{2}{*}{ Treatment } & \multicolumn{2}{c}{ Aboveground biomass $(\mathrm{g})$} & \multicolumn{2}{c|}{ Belowground biomass $(\mathrm{g})$} & \multicolumn{2}{c|}{ Leaf area $\left(\mathrm{cm}^{2}\right)$} \\
Ryegrass & Mean & Std. error & Mean & Std. error & Mean & Std.error \\
1. Control & 175.0 & 7.89 & 12.8 & 0.89 & 63.02 & 3.07 \\
2. Maple batch BC & 136.2 & 3.45 & 8.21 & 0.27 & 52.70 & 1.29 \\
3. Spruce batch BC & 126.9 & 6.29 & 8.32 & 0.61 & 51.40 & 2.4 \\
4. Maple flow through BC & 131.3 & 4.76 & 8.32 & 0.30 & 51.55 & 1.63 \\
5. BC 5 t/ha & 144.5 & 43.53 & 8.38 & 3.08 & 57.13 & 17.08 \\
6. BC 10 t/ha & 133.8 & 44.80 & 8.65 & 3.34 & 52.71 & 16.23 \\
7. BC 20 t/ha & 134.76 & 39.00 & 8.6 & 3.11 & 53.16 & 1.65 \\
8. BC 50 t/ha & 114.93 & 41.39 & 7.33 & 3.62 & 45.23 & 14.54 \\
9. BC mixed & 142.5 & 5.50 & 8.92 & 0.42 & 55.65 & 1.92 \\
10. BC top-dressing & 120.32 & 5.36 & 7.59 & 0.43 & 48.06 & 1.91 \\
Clover & & & & & & \\
1. Control & 7.97 & 1.03 & 1.98 & 0.45 & 13.66 & 2.91 \\
2. Maple batch BC & 5.29 & 0.40 & 1.58 & 0.13 & 11.11 & 0.88 \\
3. Spruce batch BC & 5.07 & 0.62 & 1.65 & 0.19 & 11.80 & 1.32 \\
4. Maple flow through BC & 4.72 & 0.46 & 1.57 & 0.11 & 11.05 & 0.78 \\
5. BC 5 t/ha & 5.15 & 0.51 & 1.63 & 0.14 & 11.27 & 1.09 \\
6. BC 10 t/ha & 5.89 & 0.62 & 1.85 & 0.18 & 13.4 & 1.19 \\
7. BC 20 t/ha & 5.15 & 0.68 & 1.85 & 0.19 & 12.9 & 1.24 \\
8. BC 50 t/ha & 3.40 & 0.41 & 1.07 & 0.10 & 7.84 & 0.89 \\
9. BC mixed & 4.51 & 0.34 & 1.54 & 0.10 & 10.62 & 0.733 \\
10. BC top-dressing & 5.54 & 0.46 & 1.66 & 0.13 & 12.06 & 0.91 \\
\hline & & & & & & \\
\hline
\end{tabular}

2

3 


\section{Table 4 (on next page)}

Mean values for plant growth responses to treated biochar

Table 4. Mean values for aboveground biomass (g), belowground biomass (g), and leaf area $\left(\mathrm{cm}^{2}\right)$ for ryegrass grown in $10 \mathrm{t} / \mathrm{ha}$ of fresh or treated (convection heated or water washed) maple and maple / birch sawdust biochar produced in a flow-through screw fed pyrolyzer with highest treatment temperature of $500-600^{\circ} \mathrm{C}(\mathrm{MFT})$, and values for ryegrass grown with $10 \mathrm{~mL}$ of "leachate" from water-washing of fresh biochars (Experiment 2). 


\begin{tabular}{|lcccccc|}
\hline & \multicolumn{2}{c}{ Aboveground biomass $(\mathrm{g})$} & \multicolumn{2}{c|}{ Belowground biomass $(\mathrm{g})$} & \multicolumn{2}{c|}{ Leaf area $\left(\mathrm{cm}^{2}\right)$} \\
\cline { 2 - 7 } Treatments & Mean & Std. error & Mean & Std. error & Mean & Std. error \\
1. Control & 195.50 & 10.59 & 122.20 & 12.57 & 63.74 & 2.50 \\
2. Biochar & 150.27 & 9.07 & 91.33 & 6.45 & 47.65 & 2.36 \\
3. Water Washed $30 \mathrm{~min}$ & 157.13 & 11.13 & 88.13 & 7.37 & 49.10 & 2.07 \\
4. Water washed $24 \mathrm{hrs}$ & 202.13 & 9.46 & 116.31 & 8.84 & 59.19 & 1.90 \\
5. Heated $50^{\circ} \mathrm{C}$ & 170.81 & 9.24 & 103.31 & 5.50 & 53.72 & 2.36 \\
6. Heated $100^{\circ} \mathrm{C}$ & 187.18 & 1.45 & 101.69 & 1.02 & 57.84 & 0.31 \\
7. Heated $150^{\circ} \mathrm{C}$ & 193.75 & 1.48 & 105.12 & 0.80 & 57.20 & 0.49 \\
8. Leachate $30 \mathrm{~min}$ & 141.75 & 7.24 & 98.88 & 7.37 & 56.69 & 4.37 \\
9. Leachate $24 \mathrm{hrs}$ & 116.38 & 5.35 & 78.38 & 7.48 & 46.53 & 1.50 \\
\hline
\end{tabular}

2 